\title{
Development of Project-Based Learning Methods in the Digital System Design Course
}

\author{
Ratna Aisuwarya ${ }^{1, *}$ Rian Ferdian ${ }^{2}$ \\ ${ }^{1}$ Department of Computer Engineering, Faculty of Information Technology, Andalas University \\ ${ }^{2}$ Department of Computer Engineering, Faculty of Information Technology, Andalas University \\ *Corresponding author.Email: aisuwarya@it.unand.ac.id
}

\begin{abstract}
The brief description of the Digital System Design course discusses the basic principles of digital system design, digital system design parameters, analysis and synthesis of combinational and sequential logic circuits, use of state diagrams in digital system design, modeling and simulating systems designs, formal verification methodologies for designs, fault models, design testing, design constraints, and design optimization techniques. The learning method applied in the previous year is the Teacher-Centered Learning (TCL) method. Based on the previous year's assessment result, the level of difficulty in this subject is classified as high, so it is necessary to change the learning method so that students can learn more effectively and efficiently. This course's learning method development is the studentcentered learning (SCL) learning method, specifically Project Based Learning (PjBL). The implementation of the project-based learning model is proven to enhance the process and achievement of student learning outcomes in the Digital System Design course by providing projects according to the topics discussed. Assignments are given during in-class sessions every week and discussed in the subsequent lecture session based on students' feedbacks. The final assessment results show an improvement in the distribution of grades.
\end{abstract}

Keywords: Project-Based Learning, Digital System Design, Student Assessment

\section{INTRODUCTION}

Education, which is one of humanity's dynamic manifestations, is inseparable from cultural changes in human life, such as communication and information technology (ICT) in everyday life [1]. The Covid-19 pandemic situation has forced all education and teaching lines to transform into online learning. In its implementation with today's technology applications, .

Based on a preliminary study on the Computer Engineering Department's undergraduate students at Andalas University, Padang, an e-learning support facility called i-learn, has indeed been developed. However, its implementation is still not optimal because not all lectures use i-learn media.

The Digital System Design course is a 3 credits compulsory subject for the Computer Systems study program in the fourth semester in Computer Architecture. The prerequisite for this Digital System Design course is Digital Logic Series. Contribution of competence/learning outcomes of this course to competence/learning outcomes in the study program curriculum includes mastery of computing, proficiency in using computing techniques and devices.

The brief description of the Digital System Design course discusses the basic principles of digital system design, digital system design parameters, analysis and synthesis of combinational and sequential logic circuits, use of state diagrams in digital system design, modeling, and simulating systems designs, formal verification methodologies for designs, fault models, design testing, design constraints, and design optimization techniques.

The learning objectives of the Digital System Design course from the Hard Skills aspect includes (1). Students understand the basic principles of digital system design, digital system design parameters, (2). Students can analyze and synthesize combinational and sequential logic circuits, and (3). Students understand the use of state diagrams in digital system design and can model and simulate system designs; to , the soft skills aspect includes (1). Students are able to apply the principles of 
cooperation, discussion, synergy, and solving problems in discussion groups [2].

The learning outcomes in the Digital System Design course are: (1). Students are able to understand the basic principles of digital system design and digital system design parameters (2). Students are able to analyze and synthesize combinational and sequential logic circuits, (3). Students are able to use state diagrams in digital system design and model and simulate system designs (5) [3]. (4) Able to be responsible for achieving group work results and supervise and evaluate the completion of work assigned to workers under their responsibility.

This course contributes to the learning outcomes of graduates formulated by the Computer Engineering Study Program according to the curriculum, which includes: (1). Think critically, identify the root of the problem, solve it comprehensively, and make the right decisions based on analysis of information and data, (2). Have adequate knowledge related to how computer systems work and are able to design and develop various digital-based product products, (3). Describe the theory and concepts for designing, creating, and testing digital system devices, (4). Describe the theory and concepts of embedded systems (embedded systems) to develop and optimize embedded systems, including software, (5). Apply basic natural science concepts in electronics and computers, and (6). Embedded systems design for specific purposes/users [4].

The learning method applied in the previous academic year (2018/2019) is the Teacher-Centered Learning (TCL) method. At the beginning of the lecture, lecturers explain the material to be discussed for the 14 times meeting in the syllabus and discuss the course's contract and rules. Lecture rules and procedures for calculating grades (Exercises, quizzes, final project, midterm exam, and final term exam) are also delivered to the students. The weight of each assessment component is: (1) Attendance: $5 \%$, (2) Mid-term exam:

$30 \%$, (3) Final term exam: 30\%, (4). Assignments and Quizzes: 20\%, and (5) Final project: 15\%. The distribution of grades for the Digital System Design course in the academic year of 2018/2019 is shown in the following graph (Figure 1).

The assessment results show that the frequency of $\mathrm{A}$, $\mathrm{A}-$ and $\mathrm{B}+$ grades are still low, namely: $0 \%, 2.9 \%$, $2.9 \%, \mathrm{~B}$ grade are $16.2 \%$ and $\mathrm{B}-38.2 \%$, while the $\mathrm{C}+$ grade are $33.8 \%$. $\mathrm{C} 2.9 \%$, and $\mathrm{C}-0 \%$, the $\mathrm{D}$ is at $2.9 \%$. It shows that the level of difficulty in this subject is classified as high, so it is necessary to change the learning method so that students are able to learn more effectively and efficiently.

This course's learning method is the student- centered learning (SCL) learning method, specifically Project Based Learning (PjBL). PjBL is an innovative learning model that involves project work where students work independently to construct their way of learning and resume it in real products. Students mustplay an active role in a way they choose accordingly based on their capacities and the topic being discussed, both in groups and personally. Each student gets an assessment of his activities at each lecture session. The aspects assessed in each of these sessions are attendance, proactive level, and student success rate in solving the problems/assignments given. Students interact with each other to obtain and practice elements of lecture material in order to achieve general learning outcomes. This method can build collaborative skills and interpersonal skills with individual and group responsibilities, personal interaction, positive interdependence, and group processes.

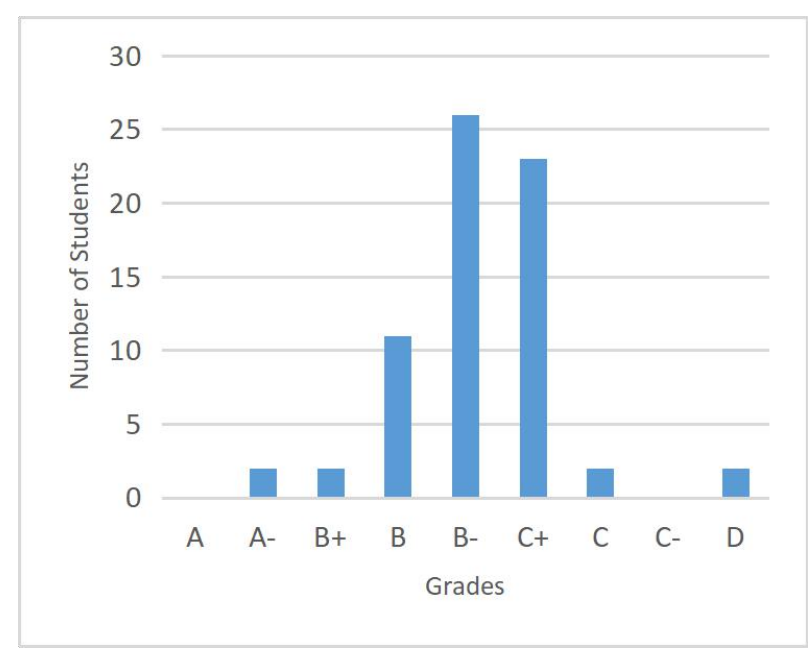

Figure 1 Grades Distribution of the Digital System Design Course for 2018/2019 Academic Year

As for Student Assessment, it consists of assessing learning outcomes and assessing the process. Assessment of learning outcomes consists of group assignments, midterm exam, and final term exam. Process assessment consists of assessment of soft skill competencies, both intrapersonal skills (including independence, critical thinking, and analytical skills), interpersonal skills (including teamwork and oral communication) and fundamental student values (including integrity, discipline, hard work, politeness/ethical and selfconfidence).

\section{METHODS}

In this study, the type of research implemented is classroom action research which was conducted from February to June 2020. Research subjects are Computer Engineering students taking the Digital System Design course, as many as 72 persons. The action procedure applied refers to the model class action research's main aspects, namely planning, implementing, observing, and reflecting. The action in this study was carried out in two cycles. Each cycle implements steps, namely (1) Start with the Essential Question, (2) Design a Plan for the 
Project. (3) Create a Schedule, (4) Monitor the Students and the Progress of the Project, (5) Assess the Outcome, (6) Evaluate the Experience [5]. The validity used in this study is content validity. The instrument content validity refers to the extent to which the instrument items cover the overall situation to be measured. Data collection instruments used in this study were through observation and surveys. The observation technique is a monitoring technique that is carried out by making observations of the measurement targets using observation sheets prepared in advance. Observation in this research involves making direct observations and taking notes regarding the implementation of learning in the lecture class. Interview technique or interview is a technique of obtaining data by holding direct dialogue with the subject. This interview is needed to obtain feedback from the learning process that is already taking place which is then used to prepare actions in planning the management of learning at a later stage [6].

The data analysis technique in this research is descriptive qualitative analysis, in this case, by a survey instrument. The analysis is described and then conclusions are drawn. The data analysis process in this study follows the model of Miles and Huberman, namely the steps of data analysis consisting of three activity lines simultaneously, including data reduction, data presentation, and conclusion. Researchers and collaborators carried out data collection from observations. Observations were made during the research implementation stage. Qualitative data is taken from the results of a survey that has been conducted by the observers [7]. The observer recorded and collected data through interviews with each student.

\section{RESULTS AND DISCUSSION}

This study aims to apply and develop a project- based learning model in the Digital System Design course in the Computer Engineering Department, Faculty of Information Technology, Andalas University. Phase 1 was applied using Combinational Logic Circuits Design lecture materials, including 7 class meetings with 2.5 hours in a class meeting. From the results of the pre-test conducted at the beginning of the lecture to find out the students' abilities related to the prerequisite courses, the results show that there are as many as $35 \%$ of students are in good competency level, $40 \%$ are in moderate competency level, and $25 \%$ are in low category level. This condition creates difficulties in implementing the learning method. If learning starts from the basic level, students who already have good competence will certainly feel bored and do not get additional knowledge even though they attend lectures. Conversely, if learning is carried out at a high level, students whose competence are still low are certainly not be able to follow lectures, considering that the Digital System Design course is a course that demands structured skills.Therefore, in this study, project-based learning was implemented. The lecturer provides framework that must be followed by students. The detailed provisions related to the design project according to the topic are submitted to students. Information related to the designed project will be discussed in small groups with reference sources from books and other materials from the internet. From phase 1 in general, it can be concluded that project-based learning in the Digital System Design course has been applied, but several aspects are still constrained and are not in line with expectations. Although this study's main target is to improve student learning achievement in the form of final assessment scores, the side effects stated in the observation table will also be improved through this research. Therefore, it is necessary to do a second phase by improving the problem in phase 1 . Constraints are still mostly found in sub-indicators: content, activities, conditions, and results.

The implementation of project-based learning in phase 2 is carried out by making improvements: (a) It is necessary to redesign the learning method so that students are not too focused on the final project results but more on the project completion process. (b) Monitoring the division of tasks in groups needs to be carried out. (c) Feedback to students needs to be given as soon as possible. The implementation of phase 2 in this study uses sequential logic circuit material. Due to the covid-19 pandemic situation, lectures in phase 2 were held 7 times through online learning media, and video meeting zoom applications), with duration of 40 minutes each class session. The research procedure is still carried out using classroom action research by making improvements, as stated in the planning phase 2 above. The learning design results and student achievement levels for phases 1 and 2, as shown in Table 1 and Table 2 .

From phase 2 in general, it can be concluded that project-based learning in the digital system design course has gone well, and the results are as expected. The main target of this research is to improve student achievement. Likewise, as stated in the observation table, the accompanying effects have also shown results that are as expected. Through this research, it can be concluded that the implementation of project-based learning in the Digital System Design course can improve student learning achievement. This learning model will be more 
Table 1. Learning Design Results and Student Achievement Level for Phase 1

\begin{tabular}{|c|c|c|c|}
\hline No. & Indicator & Sub-Indicator & Result \\
\hline \multirow{2}{*}{1} & \multirow{2}{*}{$\begin{array}{l}\text { Project } \\
\text { Theme }\end{array}$} & Suitability for the subject & $\begin{array}{l}\text { The project is a combinational circuit design using Verilog's } \\
\text { Hardware Description Language (HDL) in the ModelSim } \\
\text { program. }\end{array}$ \\
\hline & & $\begin{array}{l}\text { Compatibility with } \\
\text { relevant topics }\end{array}$ & $\begin{array}{l}\text { Projects that are undertaken are selected based on the } \\
\text { discussion topic and linked to real implementations that may } \\
\text { exist. }\end{array}$ \\
\hline \multirow{4}{*}{2} & \multirow{4}{*}{ Content } & $\begin{array}{l}\text { The complexity of the } \\
\text { problem }\end{array}$ & $\begin{array}{l}\text { Lecturers only provide a broad outline to students. The detailed } \\
\text { design is submitted to the students. }\end{array}$ \\
\hline & & $\begin{array}{l}\text { Student think } \\
\text { comprehensively }\end{array}$ & $\begin{array}{l}\text { Students are required to be able to design following the circuit } \\
\text { function and system design rules. }\end{array}$ \\
\hline & & Students' motivation & $\begin{array}{l}\text { Students who have initial abilities are in good categories and } \\
\text { have high enough motivation to complete project assignments. } \\
\text { However, students who have low initial abilities tend to be less } \\
\text { motivated to think in complex ways about the given } \\
\text { assignment. }\end{array}$ \\
\hline & & $\begin{array}{l}\text { Students' interest in the } \\
\text { given problem }\end{array}$ & $\begin{array}{l}\text { Students who have initial abilities in good and sufficient } \\
\text { categories also show a sense of interest in problems that arise } \\
\text { when designing digital systems. Students who have low initial } \\
\text { abilities tend to be less interested in design problems because } \\
\text { they find it difficult to run the ModelSim program. }\end{array}$ \\
\hline \multirow{5}{*}{3} & \multirow{5}{*}{ Activity } & Investigations by students & $\begin{array}{l}\text { Students are mostly active in investigating project assignments, } \\
\text { either through trials using a simulation program or searching for } \\
\text { reference sources from the internet. }\end{array}$ \\
\hline & & $\begin{array}{l}\text { Problem-solving by } \\
\text { students }\end{array}$ & $\begin{array}{l}\text { If students experience problems in the design process, it is } \\
\text { advisable to find a solution through a series simulation before } \\
\text { making the Verilog program. If they still do not find a solution, it } \\
\text { is assisted by the lecturer. In phase } 1 \text {, some students } \\
\text { experienced many problems, but only a few could solve them } \\
\text { independently. }\end{array}$ \\
\hline & & $\begin{array}{l}\text { Students connect the } \\
\text { relationship between their } \\
\text { ideas }\end{array}$ & $\begin{array}{l}\text { The linkage between students' ideas in phase } 1 \text { has occurred, } \\
\text { but there are still frequent errors in connecting them, and } \\
\text { students have not done an in-depth analysis. }\end{array}$ \\
\hline & & $\begin{array}{l}\text { Students use a simulator } \\
\text { program }\end{array}$ & $\begin{array}{l}\text { The program used in this lecture is a simulator with the same } \\
\text { equipment and functions as the actual hardware. }\end{array}$ \\
\hline & & $\begin{array}{l}\text { Students provide } \\
\text { feedback }\end{array}$ & $\begin{array}{l}\text { The feedback made by students is still lacking. Because } \\
\text { students have not done much in-depth analysis, so they often } \\
\text { unconsciously make mistakes in making designs. }\end{array}$ \\
\hline \multirow{4}{*}{4} & \multirow{4}{*}{ Condition } & $\begin{array}{l}\text { Students place } \\
\text { themselves according to } \\
\text { the role of a digital } \\
\text { system designer }\end{array}$ & $\begin{array}{l}\text { Students who have initial abilities in good and sufficient } \\
\text { categories can play a designer role in completing the task. } \\
\text { However, students who have low initial abilities tend to be less } \\
\text { able to act as a designer and focus more on learning how to } \\
\text { use the tools in the ModelSim program. }\end{array}$ \\
\hline & & $\begin{array}{l}\text { Time management by } \\
\text { students }\end{array}$ & $\begin{array}{l}\text { The time given to students to complete each task is } 2.5 \text { hours } \\
\text { in one class meeting session. If it is not finished, a time } \\
\text { extension outside the class meeting session is given and } \\
\text { conducted according to students' competence among the } \\
\text { group and the division of tasks. }\end{array}$ \\
\hline & & Student self-evaluation & $\begin{array}{l}\text { In phase 1, the self-evaluation of most students has not yet } \\
\text { been conducted. Self-evaluation will only work if the lecturer } \\
\text { gives inducement to student work, especially for students with } \\
\text { good initial abilities. }\end{array}$ \\
\hline & & $\begin{array}{l}\text { Work simulation by } \\
\text { students }\end{array}$ & $\begin{array}{l}\text { Project simulation in phase } 1 \text { has not shown any } \\
\text { significant results. Many students each are at the level of } \\
\text { understanding the functions of the ModelSim program's tools } \\
\text { rather than showing their performance as a designer. }\end{array}$ \\
\hline \multirow[b]{3}{*}{5} & \multirow[b]{3}{*}{ Result } & $\begin{array}{l}\text { The outcome of project } \\
\text { work }\end{array}$ & $\begin{array}{l}\text { The average student project work achievement in phase } 1 \text { was } \\
72 \text { percent. }\end{array}$ \\
\hline & & $\begin{array}{l}\text { Self-assessment by } \\
\text { students }\end{array}$ & $\begin{array}{l}\text { Students' self-assessment in phase } 1 \text { did not run well because } \\
\text { students still had difficulty understanding the lecturer's } \\
\text { standards in designing projects. }\end{array}$ \\
\hline & & Student responsibility & $\begin{array}{l}\text { All students have shown their responsibility, which can be seen } \\
\text { from their seriousness in doing assignments. The lecturer has } \\
\text { explained to students that each meeting must collect the } \\
\text { assignment given. }\end{array}$ \\
\hline
\end{tabular}


Student competencies

include social skills,

management, and engineering.
Since the start of the class, students' social skills are quite good, but they still lack management skills and techniques, especially time management.

Table 2. Learning Design Results and Student Achievement Level for Phase 2

\begin{tabular}{|c|c|c|c|}
\hline No. & Indicator & Sub-Indicator & Result \\
\hline \multirow[b]{2}{*}{1} & \multirow{2}{*}{$\begin{array}{l}\text { Project } \\
\text { Theme }\end{array}$} & Suitability for the subject & $\begin{array}{l}\text { The project is a combinational circuit design using Verilog's } \\
\text { Hardware Description Language (HDL) in the ModelSim } \\
\text { program. }\end{array}$ \\
\hline & & $\begin{array}{l}\text { Compatibility with } \\
\text { relevant topics }\end{array}$ & $\begin{array}{l}\text { Projects that are undertaken are selected based on the } \\
\text { discussion topic and linked to real implementations that may } \\
\text { exist. }\end{array}$ \\
\hline \multirow{4}{*}{2} & \multirow{4}{*}{ Content } & $\begin{array}{l}\text { The complexity of the } \\
\text { problem }\end{array}$ & $\begin{array}{l}\text { Lecturers only provide a broad outline to students. The detailed } \\
\text { design is submitted to the students. }\end{array}$ \\
\hline & & $\begin{array}{l}\text { Student think } \\
\text { comprehensively }\end{array}$ & $\begin{array}{l}\text { Students are able to design following the circuit function and } \\
\text { system design rules. }\end{array}$ \\
\hline & & Students' motivation & $\begin{array}{l}\text { Students are motivated to think in complex ways about the } \\
\text { given project. Students whose initial abilities are low still have } \\
\text { high enough motivation thanks to the implementation of peer } \\
\text { tutors. }\end{array}$ \\
\hline & & $\begin{array}{l}\text { Students' interest in the } \\
\text { given problem }\end{array}$ & $\begin{array}{l}\text { Students show a sense of interest in problems that arise when } \\
\text { designing digital systems. Lecturers provide flexibility for } \\
\text { students to improvise in order to develop student innovations } \\
\text { and creations. }\end{array}$ \\
\hline \multirow{5}{*}{3} & \multirow{5}{*}{ Activity } & Investigations by students & $\begin{array}{l}\text { Students actively investigate project assignments, either } \\
\text { through trials using a simulation program or searching for } \\
\text { reference sources from the internet. }\end{array}$ \\
\hline & & $\begin{array}{l}\text { Problem-solving by } \\
\text { students }\end{array}$ & $\begin{array}{l}\text { Most of the problems faced by students have been resolved by } \\
\text { doing discussions among students. Even though they have } \\
\text { held discussions, only a small proportion of them have not } \\
\text { found the answer to the solution. }\end{array}$ \\
\hline & & $\begin{array}{l}\text { Students connect the } \\
\text { relationship between their } \\
\text { ideas }\end{array}$ & $\begin{array}{l}\text { The linkage between student ideas has worked well, } \\
\text { accompanied by in-depth analysis through peer-to-peer } \\
\text { discussions. }\end{array}$ \\
\hline & & $\begin{array}{l}\text { Students use a simulator } \\
\text { program }\end{array}$ & $\begin{array}{l}\text { The program used in this lecture is a simulator with the same } \\
\text { equipment and functions as the actual hardware. }\end{array}$ \\
\hline & & $\begin{array}{l}\text { Students provide } \\
\text { feedback }\end{array}$ & $\begin{array}{l}\text { Students always make improvements to the assignments that } \\
\text { have been submitted to the lecturers. Lecturers always provide } \\
\text { suggestions for student assignments that are not correct. }\end{array}$ \\
\hline \multirow{4}{*}{4} & \multirow{4}{*}{ Condition } & $\begin{array}{l}\text { Students place } \\
\text { themselves according to } \\
\text { the role of a digital } \\
\text { system designer }\end{array}$ & $\begin{array}{l}\text { Students can act as designers in completing their assignments } \\
\text { while learning how to use the ModelSim program tools. }\end{array}$ \\
\hline & & $\begin{array}{l}\text { Time management by } \\
\text { students }\end{array}$ & $\begin{array}{l}\text { The time given to students to complete each task is } 2.5 \text { hours } \\
\text { in one class meeting session. If it is not finished, a time } \\
\text { extension outside the class meeting session is given and } \\
\text { conducted according to students' competence among the } \\
\text { group and the division of tasks. }\end{array}$ \\
\hline & & Student self-evaluation & $\begin{array}{l}\text { Students can carry out self-evaluation based on the lecturer's } \\
\text { suggestions from the previously collected assignments. }\end{array}$ \\
\hline & & $\begin{array}{l}\text { Work simulation by } \\
\text { students }\end{array}$ & $\begin{array}{l}\text { Project simulation in phase } 2 \text { has shown significant results. } \\
\text { Students start to show their performance as a designer. }\end{array}$ \\
\hline \multirow{4}{*}{5} & \multirow{4}{*}{ Result } & $\begin{array}{l}\text { The outcome of project } \\
\text { work }\end{array}$ & $\begin{array}{l}\text { The average student project work achievement in phase } 2 \text { was } \\
81 \text { percent. }\end{array}$ \\
\hline & & $\begin{array}{l}\text { Self-assessment by } \\
\text { students }\end{array}$ & $\begin{array}{l}\text { Self-assessment by students has gone well. Students can } \\
\text { estimate their grade when submitting project assignments } \\
\text { based on the lecturer's assessment criteria. }\end{array}$ \\
\hline & & Student responsibility & $\begin{array}{l}\text { All students have shown their responsibility, which can be seen } \\
\text { from their seriousness in doing assignments. The lecturer has } \\
\text { explained to students that each meeting must collect the } \\
\text { assignment given. }\end{array}$ \\
\hline & & $\begin{array}{l}\text { Student competencies } \\
\text { include social skills, } \\
\text { management, and } \\
\text { engineering. }\end{array}$ & $\begin{array}{l}\text { Since the start of the class, students' social skills are quite } \\
\text { good. Students have demonstrated time management. The } \\
\text { technical competence of students has shown improvement. }\end{array}$ \\
\hline
\end{tabular}


suitable for the Digital System Design course after the following developments are carried out: (1) The project theme uses the subject's main competencies, namely making digital system design. (2) The lecture's content is designed so that students can design and analyze based on the project they are working on. (3) Student activities are designed to be active, innovative, creative, practical, and fun. The classmate tutor model can support student learning activities, despite online communication is constrained. (4) The learning process must always be monitored by the lecturer, not only focused on learning outcomes.

\section{CONCLUSION}

The implementation of the project-based learning model is proven to enhance the process and student learning outcomes in the Digital System Design course by providing projects according to the topics discussed. Assignments are delivered in-class sessions every week and discussed in the next lecture session based on their feedbacks. The final assessment results show an improvement compared to the distribution of the grades in the previous semester. The distribution of grades for the Digital System Design course in the academic year of $2019 / 2020$ is shown in the following graph (Figure 2).

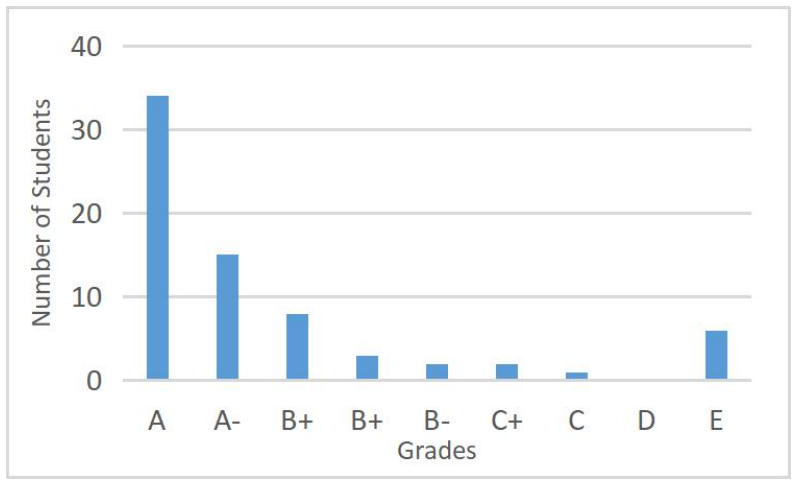

Figure 2 Grades Distribution of the Digital System Design Course for 2019/2020 Academic Year

\section{ACKNOWLEDGMENTS}

This research work was supported by Andalas University, Indonesia.

\section{REFERENCES}

[1] Altay, B. User-Centered Design through LearnerCentered Instruction. Teaching in Higher Education, 19(2), pp. 138-155, 2013.

[2] Harmer, N. Project-Based Learning, Literature Review. [pdf] Plymouth: Plymouth University, pp. 1-
34, 2014. Available at: https://www.plymouth.ac.uk/ uploads/production/document/path/2/2733/Literatu re_review_Project-based_learning.pdf [Accessed 25 Sept. 2020.

[3] Henri, T. R. Forming Productive Student Groups Using a Massively Parallel Brute-Force Algorithm. Lecture Notes in Engineering and Computer Science, 1, pp.108-112. 2013.

[4] Lathika, K. Student Centred Learning. International Journal of Current Research and Modern Education 1(1), pp. 677-680. 2016.

[5] Lee, J. S., Blackwell, S., Drake, J. and Moran, K. A. Taking a Leap of Faith: Redefining Teaching and Learning in Higher Education through Project- Based Learning. Interdisciplinary Journal of Problem-Based Learning, 8(2), pp. 19-34. 2014.

[6] Vasilienè-Vasiliauskienè, V., Butviliene, J. and Butvilas, T. Project-Based Learning: The Complexity and Challenges in Higher Education Institutions. Computer Modeling \& New Technologies, 20(2), pp. 7-10. 2016.

[7] Woro, S. The Strengths and Weaknesses of the Implementation of Project Based Learning: A Review. International Journal of Science and Research (IJSR), 4(3), 478-484, 2015. 